\title{
Adherence to the five moments for hand hygiene among intensive care professionals
}

\author{
Adesão dos profissionais de terapia intensiva aos cinco momentos da higienização das mãos \\ Adherencia de los profesionales de una unidad de cuidados \\ intensivos a los cinco momentos de higiene de las manos \\ Luccas Melo de Souza ${ }^{a}$ \\ Maríndia Fernandes Ramos ${ }^{b}$ \\ Evelin Santos da Silva Becker ${ }^{c}$ \\ Lisiani Celina da Silva Meirelles ${ }^{\mathrm{a}}$ \\ Suzana Aparecida Oliveira Monteiro ${ }^{d}$
}

DOl: $\quad$ http://dx.doi.org/10.1590/1983-

1447.2015.04.49090

\footnotetext{
- Universidade Luterana do Brasil (ULBRA), Campus Gravataí. Gravataí, Rio Grande do Sul, Brasil.

• Hospital Dom João Becker, Gravataí, Rio Grande do Sul, Brasil.

Hospital Universitário, Canoas, Rio Grande do Sul, Brasil.

¿ Grupo Fleury, Porto Alegre, Rio Grande do Sul, Brasil.
}

\section{ABSTRACT}

Objective: to identify the adherence of health professionals of an intensive care unit to the five moments for hand hygiene. Method: cross-sectional analytical study with a quantitative approach, based on secondary data from a database of a hospital infection control service at an institution in southern Brazil. A total of 793 observations were analyzed from July to December 2012.

Results: hand washing was not performed in 446 (56.2\%) of the observations, and the adherence rate was $43.7 \%$. The greatest adherence to hand hygiene was among the physiotherapists (53.5\%) and the lowest adherence was among the nursing staff (29.2\%). The indications with the lowest adherence rates to hand hygiene were "before touching the patient" (18.4\%) and "before aseptic procedure" (20.9\%).

Conclusion: we conclude that adherence to hand washing does not comply with the national and international guidelines, especially when we consider the current scenario of growing infections caused by multidrug-resistant microorganisms.

Keywords: Nursing. Intensive care. Cross infection. Hand hygiene. Hand disinfection. Patient safety.

\section{RESUMO}

Objetivo: Identificar a adesão dos profissionais de saúde de uma Unidade de Terapia Intensiva aos cinco momentos de higienização das mãos.

Método: Estudo transversal analítico, com abordagem quantitativa, embasado em dados secundários de um banco de dados de um Serviço de Controle de Infecção Hospitalar de uma instituição do sul do Brasil. Foram analisadas 793 observações de julho a dezembro de 2012.

Resultados: Em 446 (56,2\%) observações, não ocorreu a higienização das mãos, ficando a taxa de adesão em 43,7\%. A maior adesão à higienização das mãos foi dos fisioterapeutas (53,5\%) e a menor, dos técnicos de enfermagem (29,2\%). As indicações com menor adesão à higienização das mãos foram "antes do contato com o paciente" (18,4\%) e"antes de procedimento asséptico" (20,9\%). Conclusão: A prática de higienização das mãos está distante das diretrizes nacionais e internacionais, principalmente frente ao cenário atual de aumento de infecções por microrganismos multirresistentes.

Palavras-chave: Enfermagem. Terapia intensiva. Infecção hospitalar. Higiene das mãos. Desinfecção das mãos. Segurança do paciente.

\section{RESUMEN}

Objetivo: identificar la adherencia de los profesionales sanitarios de una Unidad de Cuidados Intensivos a los cinco momentos de la higiene de manos.

Método: estudio de corte transversal analítico con un enfoque cuantitativo, basado en datos secundarios de una base de datos de un servicio de Control de Infecciones en una institución en el sur de Brasil. Se analizaron 793 observaciones, de julio a diciembre de 2012. Resultados: En 446 (56,2\%) de las observaciones no se produjo la higiene de manos, y la tasa de adhesión fue de 43,7\%. La mayor adherencia a la higiene de las manos fue de fisioterapeutas (53,5\%) y el más bajo del personal de enfermería (29,2\%). Indicaciones con menor adhesión a la higiene de manos fueron los "antes del contacto con el paciente" $(18,4 \%)$ y "antes del procedimiento aséptico" $(20,9 \%)$.

Conclusión: Llegamos a la conclusión de que la práctica de la higiene de las manos es distante de las directrices nacionales e internacionales, sobre todo a causa de la situación actual de aumento de las infecciones por microorganismos multirresistentes.

Palabras clave: Enfermería. Cuidados intensivos. Infección hospitalaria. Higiene de las manos. Desinfección de las manos. Seguridad del paciente. 


\section{DINTRODUCTION}

Hand hygiene is considered the most effective way to reduce healthcare-associated infections (HAl) as it prevents the cross-transmission of microorganisms ${ }^{(1)}$. Healthcare must be provided with awareness, professional responsibility and commitment to the health and safety of others, free of avoidable harm, as specified in the codes of ethics of healthcare professions ${ }^{(2)}$. Consequently, hand hygiene is a patient safety component that reduces the risk of preventable healthcare-associated harm to a minimum acceptable level(3).

The hand hygiene campaign (entitled "Clean Care is Safer Care") was inserted into the World Alliance for Patient Safety and adopted by the World Health Organization (WHO) in 2004 as the first step toward promoting patient safety. Brazil was included in the Alliance in 2007 with the political commitment to improve health-related issues, especially reducing the risks of $\mathrm{HAl}^{(4-5)}$.

The WHO recommends hand hygiene in all health units, regardless of the resources available. To facilitate the process, the WHO indicates the five moments for hand hygiene, as follows: (i) before touching a patient; (ii) before clean/aseptic procedure (like inserting catheters or administering intravenous medication); (iii) after body fluid exposure risk (like blood, saliva or sweat); (iv) after touching a patient; and ( $v$ ) after touching patient surroundings (furniture, doorknobs, infusion pumps or any surface close to the patient $)^{(5)}$.

The aim of hand hygiene is to remove dirt, organic material and/or micro-organisms to prevent transmission. It can occur in four ways: simple hand hygiene (with soap and water); hand washing with antiseptic agent; antiseptic hand rub (provided there is no visible dirt) and surgical hand rub/scrub ${ }^{(6)}$.

An estimated 1.4 million people worldwide are affected by preventable healthcare-related infections. In Brazil, an estimated 3\% to 15\% of admitted patients develop some form of HAl(4), which can worsen the patient's health, extend the hospital stay, increase the costs of treatment, and may even lead to death.

In addition to the financial expenditures, $\mathrm{HAl}$ are associated with multidrug-resistant microorganisms, which has global repercussions and reveals the need to control the inspection and epidemiological blocking processes with hand hygiene. The data that are collected while monitoring hand hygiene adherence can help to guide and prepare corrective actions. When hand hygiene is observed during the daily care routine it becomes a valid indicator of patient safety ${ }^{(4)}$.
In this context, the aim of this paper is to identify adherence to the five moments for hand hygiene recommended by the WHO among health professionals of an intensive care unit.

\section{Q METHOD}

This is a cross-sectional analytical study with a quantitative approach based on secondary data obtained from the electronic database of the Serviço de Controle de Infecção Hospitalar ( $\mathrm{SClH})$, or hospital infection control service, of a hospital in southern Brazil. This database was built using daily observations/follow-up with trauma and burn patients in an intensive care unit (ICU) at a hospital in Porto Alegre. These observations are part of the daily hand hygiene routine of the $\mathrm{SClH}$.

The ICU of the hospital is composed of 28 individual beds for adults and children, divided into three nursing stations. The beds or points of care are separated by partitions and glass doors. All the points have a sink with liquid soap dispensers, paper towels and alcohol spray dispensers for antiseptic hand rubs. Each station has at least one sink for hand hygiene. One station has four sinks and the other two stations have one sink each, totalling six sinks in the nursing stations. These six sinks, in addition to the 28 sinks beside each bed, allow hand hygiene in the point of care. The alcoholic spray solution (40 dispensers in the ICU) is strategically positioned in the nursing stations and points of care. It should be noted that the point of care unites three elements: the patient, the health professional and the care/treatment, and involves contact with patients or their surroundings (within the patient zone). Hand hygiene products must be available at the point of care without the need to leave the patient area (ideally at arm's reach or within two metres) ${ }^{(7)}$.

The ICU was chosen to collect secondary data because it complies with the standards of the Agência Nacional de Vigilância Sanitária (ANVISA)(7), the national health inspection agency, for the distribution of hand hygiene materials. The study population consisted of health professionals that are directly related to ICU patient care and who were accompanied by the $\mathrm{SCIH}$ team (through the daily hand hygiene inspection routine) from July to December 2012. The criteria for inclusion were physician, physiotherapist, nurse or nursing technician of the ICU. Residents in nursing, medicine and physiotherapy respectively composed the group of nurses, doctors and physiotherapists for data analysis. The exclusion criteria were students in graduate and professional/technical level who provide on-site support services in fields such as nutrition, radiology, laboratory, blood bank or other areas of assistance. 
The data were extracted from a database used for routine hand hygiene inspection of the $\mathrm{SClH}$ of the hospital. The observations on hand hygiene adherence (a routine inspection since September 2011) are provided during the morning and evening shifts with the exception of weekends and holidays. Objective inspection supports studies and interventions on this subject by means of the direct observation of the members of the $\mathrm{SClH}$ sector. This observation is performed using a form created by the professionals according to the five moments for hand hygiene campaign of the $\mathrm{WHO}^{(2-3)}$.

Adherence to hand hygiene was monitored by observing 120 monthly hand hygiene indications divided into 30 monthly observations for each professional category. The observations occurred according to a preset scale of the $\mathrm{SCIH}$ team, in which the daily number of observations depended on the number of working days per month (about five or six observations per day) totalling a minimum of 120 monthly observations. In this way, a professional category was observed for each day without indicating to the professionals which category was being observed. The observers were nursing interns of the $\mathrm{SCIH}$ who were being trained for inspection.

The choice of the professional who would be observed depended on the presence of the professional in the ICU when the observers arrived. When the observer entered the ICU, he or she would wait for the first opportunity to accompany the professional and the category that would be observed on that day. When the professional initiated an action with a hand hygiene indication (or one of the five moments for hand hygiene of the WHO), the observer recorded the indication and the action taken on a spreadsheet. The amount of opportunities marked on the spreadsheet depended on the number of indications performed by the professional. The number of daily observations established by the $\mathrm{SCIH}$ was completed for only one observed professional. If no indications were carried out, other professionals were observed during the shift, selected in the same manner as the first, until the daily observations were completed.

It should be noted that the routine hand hygiene inspection was initially centered on the five moments for hand hygiene of the WHO. Therefore, the observations focused on whether hand hygiene was carried out or not, without observing use of the correct hand hygiene technique or the removal of jewellery and accessories.

The data from these observations were marked in printed spreadsheets and later entered into an electronic spreadsheet. The electronic software was exclusively created by the computer department of the hospital for the
$\mathrm{SCIH}$. The variables extracted for this study were: the observation shift, the professional category, hand hygiene indication (defined in this study as one of the five hand hygiene moments of the $\mathrm{WHO}$ ), and the action taken by the observed professional (hand hygiene with alcohol spray/gel, hand hygiene with soap and water or absence of hand hygiene).

We used descriptive statistics (frequency, measures of central tendency and dispersion) and analytical statistics with Pearson's Chi-square test. Two-tailed $p$ values less than 0.05 were considered to be statistically significant. The hand hygiene adherence rate was calculated by dividing the number of actions by the number of opportunities and multiplying the result by $100^{(8)}$.

The research was approved by the ethics committee of research involving human beings of the institution (opinion 301.969/2013) and of the field of study (opinion 387.535/2013). The researchers signed a statement of commitment for use of this data.

\section{RESULTS}

A total of 793 observations were completed (Table 1) in the study period, mainly in the morning shift and involving professionals with higher education. The distribution of the observations was homogeneous among the four studied categories. Proportional observations among the professional categories is a criterion of $\mathrm{SClH}$ inspection.

The indication with the lowest level of compliance was "before aseptic procedure" (5.4\%), and the indications with the highest levels of compliance were "after touching the patient" (31.3\%) and "after touching patient surroundings" (27.2\%).

In 446 (56.2\%) observations, there was no compliance with the hand hygiene indications (Table 2). Hand hygiene using soap and water was more frequent than hand rubbing using alcohol for the analysis of professional category and for the hand hygiene indication. The hand hygiene compliance rate was $43.7 \%$,

Table 3 shows the analysis of predictive variables with the outcomes divided into hand hygiene performed and hand hygiene not performed. There was no statistically significant difference in hand hygiene according to the profession and indication.

In terms of profession, the nursing technicians (29.8\%) adhered the least to hand hygiene and the physiotherapists (53.5\%) adhered the most to hand hygiene $(p<0.001)$. With respect to the indication, according to the five moments for hand hygiene, adherence $(p<0.001)$ to the indications "before touching the patient" (81.6\%) and "before 
Table 1 - Characteristics of the observations according to profession, shift and hand hygiene indication. Porto Alegre, RS, Brazil, 2012

\section{Variables}

\section{N (\%)}

\section{Profession}

$\begin{array}{lll}\text { Nurse } & 200 & 25.2 \\ \text { Doctor } & 197 & 24.8 \\ \text { Physiotherapist } & 198 & 25.0 \\ \text { Nursing technician } & 198 & 25.0\end{array}$

\section{Shift*}

$\begin{array}{lll}\text { Morning } & 501 & 72.2 \\ \text { Evening } & 188 & 27.2\end{array}$

\section{Indication}

\begin{tabular}{lcc} 
Before touching the patient & 196 & 24.7 \\
Before aseptic procedure & 43 & 5.4 \\
After risk of exposure to fluid & 90 & 11.3 \\
After touching the patient & 248 & 31.3 \\
After touching patient surroundings & 216 & 27.2 \\
\hline
\end{tabular}

Source: Serviço de Controle de Infecção Hospitalar; Research data, 2012.

$n=$ frequency; ${ }^{*}$ sample less than 793 . aseptic procedure" (79.1\%) was lower than adherence to the "after touching" indications (patient, patient surroundings or exposure to risk).

\section{DISCUSSION}

At the studied hospital, hand hygiene could be performed before and after contact with the patient or the patient surroundings because all the points of care had sinks and spray alcohol dispensers. The failure to perform hand hygiene compromises the safety of those involved due to the risk of transmitting microorganisms to the patient, to the healthcare worker, to other patients and to the patient surroundings $s^{(4)}$.

Hand hygiene did not occur in 446 (56.2\%) of the observations, which is worrying. The ratio between the number of opportunities and the number of hand hygiene activities revealed an adherence rate of $43.7 \%$, which can be considered unsatisfactory ${ }^{(2)}$ and increase the risk of hospital-acquired infection.

Conceptually, a hospital-acquired infection is considered any infection by microorganisms acquired during the hospitalization of a patient from 48 to 72 hours of admis-

Table 2 - Distribution of the variables according to type of hand hygiene conduct. Porto Alegre, RS, Brazil, 2012

\begin{tabular}{lccc}
\multicolumn{1}{c}{ Variables } & $\begin{array}{c}\text { Alcohol hand } \\
\text { hygiene } \\
\mathbf{n}(\%)\end{array}$ & $\begin{array}{c}\text { Soap and water } \\
\text { hand hygiene } \\
\mathbf{n}(\%)\end{array}$ & $\begin{array}{c}\text { No hand hygiene } \\
\mathbf{n}(\%)\end{array}$ \\
$\begin{array}{l}\text { Profession } \\
\text { Physiotherapist }\end{array}$ & $11(5.5)$ & $95(48)$ & $92(46.5)$ \\
$\quad$ Nurse & $26(13)$ & $69(34.5)$ & $105(52.5)$ \\
$\quad$ Doctor & $40(20.3)$ & $47(23.9)$ & $110(55.8)$ \\
$\quad$ Nursing technician & $16(8.1)$ & $43(21.7)$ & $139(70.2)$ \\
Total & $93(11.8)$ & $254(32)$ & $446(56.2)$ \\
Shift* & & & \\
$\quad$ Morning & $55(11)$ & $165(32.9)$ & $281(56.1)$ \\
Evening & $32(17)$ & $45(23.9)$ & $111(59.1)$ \\
Indication & & & $160(81.6)$ \\
Before touching the patient & $17(8.7)$ & $19(9.7)$ & $34(79)$ \\
Before aseptic procedure & $3(7)$ & $6(14)$ & $40(44.4)$ \\
After risk of exposure to fluid & $6(6.7)$ & $44(48.9)$ & $102(41.1)$ \\
After touching the patient & $36(14.5)$ & $110(44.4)$ & $110(50.9)$ \\
After touching patient surroundings & $31(14.4)$ & $75(34.7)$ & \\
\hline
\end{tabular}

Source: Serviço de Controle de Infecção Hospitalar; Research data, 2012.

$\mathrm{n}=$ frequency; ${ }^{*}$ sample less than 793. 
Table 3 - Distribution of the variables according to adherence to hand hygiene. Porto Alegre, RS, Brazil, 2012

\begin{tabular}{|c|c|c|c|}
\hline Variables & $\begin{array}{c}\text { Hand hygiene } \\
\text { n (\%) }\end{array}$ & $\begin{array}{c}\text { No hand hygiene } \\
\text { n (\%) }\end{array}$ & $\mathbf{p}$ \\
\hline Shift & & & $0.485^{+}$ \\
\hline Morning & $220(43.9)$ & $281(56.1)$ & \\
\hline Evening & $77(41)$ & $111(59)$ & \\
\hline Profession & & & $<0.001^{+}$ \\
\hline Physiotherapist & $106(53.5)$ & $92(46.5)$ & \\
\hline Nurse & $95(47.5)$ & $105(52.5)$ & \\
\hline Doctor & $87(44.2)$ & $110(55.8)$ & \\
\hline Nursing technician & $59(29.8)$ & $139(70.2)$ & \\
\hline Indication & & & $<0.001^{\dagger}$ \\
\hline Before touching the patient & $36(18.4)$ & $160(81.6)$ & \\
\hline Before aseptic procedure & $9(20.9)$ & $34(79.1)$ & \\
\hline After risk of exposure to fluid & $50(55.6)$ & $40(44.4)$ & \\
\hline After touching the patient & $146(58.9)$ & $102(41.1)$ & \\
\hline After touching patient surroundings & $106(49.1)$ & $110(50.9)$ & \\
\hline
\end{tabular}

Source: Serviço de Controle de Infecção Hospitalar; Research data, 2012

$\mathrm{n}=$ frequency; ${ }^{*}$ sample less than 793; $\uparrow$ Pearson Chi-square test.

sion, insofar as there is no incubation at the time of admission ${ }^{(2)}$. Hospital-acquired infections include infections after discharge that are related to the hospitalization period. Hand hygiene is considered one of the most important measures to control $\mathrm{HAl}^{(1,4-5)}$ and one of the pillars of patient safety and the fight against infection. Reports of outbreaks of multidrug-resistant gram-negative organisms in ICUs have been progressive in recent decades. These outbreaks pose a threat to patient safety and public health around the world, and they are related to low adherence to hand hygiene $\mathrm{e}^{(1)}$.

At the hospital of this study, the distribution and easy access of the material resources was significant, considering the available number of sinks (34) and constantly refilled alcohol spray dispensers (40). This distribution was adequate according to the evaluation of the $\mathrm{SCIH}$ and ANVISA requirements ${ }^{(9)}$. A study on the management of material resources for hand hygiene conducted at the ICU of a university hospital in Paraná revealed the importance of offering quality products that, in addition to promoting patient and worker safety, serve as an incentive for hand hygiene ${ }^{(10)}$. Researchers ${ }^{(11)}$ reported that the main justifications for the low adherence to hand hygiene, called hand hygiene barriers, were forgetfulness, lack of knowledge or awareness, lack of time, skin irritation and lack of materials. Consequently, multi-modal strategies need to be adopted to eliminate these barriers and increase adherence of hand hygiene in the scenario of the study. The results of these strategies are reflected in the change of culture and behaviour of health professionals and have an impact on the hand hygiene adherence indicators ${ }^{(5,12)}$.

With respect to actions by professional category, the physiotherapists (53.5\%) showed the greatest adherence to hand hygiene in the observed procedures. Of these professionals, 11 (5.5\%) used alcohol spray and 95 (48\%) used soap and water. Contrarily, the nursing technicians showed the lowest adherence to hand hygiene (29.8\%). Of this category, 16 (8.1\%) used alcohol spray and 43 (21.7\%) used soap and water. Nurses, nursing technicians and doctors presented an adherence of under $50 \%$ in the observed behaviour.

The low adherence of the nursing technicians (29.8\%) is even more worrying, since they are the professionals who are directly and continuously in contact with the patients, 24 hours a day, every day. Given this intense contact with the patients, their non-compliance with this practice puts the patients at a higher risk of infection.

A study with nurses from a hospital in Turkey ${ }^{(13)}$ showed that even when there is a frequent need for hand hygiene (as in the case of the nursing technicians in Brazil), these professionals were unable to perform hand hygiene due to the conditions and hectic pace of their work, insufficient 
materials (washbasins/dispensers and products such as soap and alcohol) and/or because they felt discomfort in their hands after frequent cleaning. Moreover, Escherichia Coli and coagulase-negative Staphylococcus sp were the most prevalent bacteria found in the culture of the hands of these nurses, highlighting the risk to patient safety and the safety of professionals due to non-compliance with hand hygiene practices.

A study conducted at a teaching hospital of the mid-western region of Brazil identified a low adherence (27.7\%) to hand hygiene, especially among the medical staff (17.5\% of the 80 hand washing indications). As for the category of nursing, including academics, nurses, nursing aides and technicians and nursing professors, 748 hand hygiene opportunities were recorded with an adherence rate of 33\% ${ }^{(14)}$.

Research conducted at a neonatal ICU of a hospital in Goiás reported that of the 1,358 procedures observed, hand hygiene was performed by $77.7 \%$ of the physiotherapists, $75.9 \%$ of the doctors, $74.3 \%$ of the nurses and $57.2 \%$ of the nursing aides and technicians. These results show a higher adherence than in the present study, but they also indicate a similarity between the professional category that adhered the most to this practice (physiotherapists) and the category that adhered the least (nursing technicians) to hand hygiene ${ }^{(15)}$.

The use of antiseptic rubbing with alcohol spray was the least preferred hand hygiene technique (11.8\%), although this technique is relatively quick and easy. There is also scientific evidence of the effectiveness of this technique when hands are visibly clean ${ }^{(1)}$. In 2010, ANVISA, based on resolution \#42 of October 25, 2010 of the Collegiate Board, established the mandatory use of liquid or gel alcohol for hand hygiene in Brazilian healthcare units ${ }^{(9)}$.

However, a study conducted at a neonatal ICU of Goiás also revealed the resistance of practitioners in relation to the use of alcohol, with an adherence rate of $2.6 \%$ before performing procedures and $1.7 \%$ after procedures ${ }^{(15)}$. A study with the nursing staff of a teaching hospital in São Paulo identified that no alcohol solution was used in any of the 1,206 observed hand hygiene opportunities ${ }^{(16)}$. In Turkey ${ }^{(17)}, 65 \%$ of the nurses of an ICU reported that hand rubbing with alcohol-based antiseptic agents was the preferred hand hygiene technique.

Another worrying factor is that non-adherence to the indication "before aseptic procedure" was observed in $81.6 \%$ of the hand hygiene situations. A barrier to hand hygiene before aseptic procedure is the use of gloves, since the professionals may wrongfully believe that gloves replace hand hygiene. The use of gloves does not replace hand hygiene regardless of the indication. It should be stressed that health professionals must provide quality care and their actions must promote health, patient safety and the safety of the medical staff(18).

With respect to the indication, according to the five moments for hand hygiene, adherence $(p<0.001)$ to the indications "before touching the patient" (81.6\%) and "before aseptic procedure" (79.1\%) was lower than adherence to the "after touching" indications (patient, patient surrounding or exposure to risk). Some studies corroborate these findings, revealing that health professionals are concerned with their own exposure to diseases after completing the procedures $^{(15)}$. A study ${ }^{(17)}$ with ICU nurses of a hospital in Turkey also revealed a higher rate of self-reported hand hygiene after touching the patient (96-100\%) versus before touching the patient (65-93\%). It should be noted that this study in Turkey reviewed the self-reporting of hand hygiene, which overestimates the adherence rate in relation to data collection by observation.

Health professionals are exposed to the risk of infection by direct contact with the patient and the patient surroundings. However, when the contact involves bodily fluids and potentially contaminated regions, adherence to hand hygiene tends to increase, which reveals the pursuit of self-care by professionals ${ }^{(12)}$. This practice prevents the spreading of microorganisms and contamination, and reduces the risk of transmission. However, not performing hand hygiene in the "before" procedures (touching the patient or aseptic procedure) is a risk to patient safety due to the transmission of microorganisms from the patient surroundings, especially considering that the ICU patients are more vulnerable to infection and the consequent clinical aggravation.

Furthermore, the personal beliefs and habits acquired during a lifetime can have a greater influence on adherence to hand hygiene than professionally constructed scientific knowledge ${ }^{(12)}$, which can also explain greater adherence to the "after touching" indications and the pursuit of self-protection of these professionals. A report that is released annually by the Kingston General Hospital (Canada) also corroborates this assertion. According to the report, from April 2014 to March 2015, the adherence rate of hand hygiene was $79.5 \%$ for the "before touching" indications and $87.5 \%$ for the "after touching" indications ${ }^{(8)}$.

The direct observation (inspection) of hand hygiene opportunities is recommended and considered a gold standard by the $\mathrm{WHO}^{(4)}$. It is also the most accepted and widely used approach by researchers. The weak point of this method is the Hawthorne effect, or when individuals improve or modify their behaviour in response to being 
observed ${ }^{(19)}$, which is one of the limitations of this study. Consequently, the observed adherence of these professionals to hand hygiene may be even lower, since they could have improved their performance during the observations. To minimize this bias, however, the chosen observers were undergraduate students instead of professionals of the institution.

\section{口FINAL CONSIDERATIONS}

The identified adherence rate to hand hygiene among the healthcare professionals of the ICU was $43.7 \%$, which can be considered low. The nursing technicians showed the lowest adherence, which is even more worrying because of the more frequent contact of these professionals with the patients. The moments "before touching the patient" and "before aseptic procedure" presented the lowest percentage of adherence, which reveals that this is the most fragile point of hand hygiene practices in the unit.

Hand hygiene inspection is essential to verify adherence to this technique. The results provide an important opportunity for reflection for healthcare managers, leaders and professionals regarding patient safety practices. It is also important to divulge the inspection results among the professionals to trigger reflection and changes in attitude. Alternatives to improve adherence to hand hygiene include the pursuit of new partners to adhere to this practice, the provision of feedback in the work environment, offering new hand hygiene methods (pocket alcohol gel), increasing the number of observing professionals and training, rethinking approaches and dynamics, conducting research with the workers to identify what they believe could improve adherence to hand hygiene practices, and implementing and encouraging awareness programmes.

Interdisciplinary and intersectoral efforts are required to change the attitude and work between the $\mathrm{SClH}$, the healthcare professionals and the other services. Greater unity between the $\mathrm{SClH}$ and its partners, such as managers, heads of department and of the professional categories, will inevitably lead to better results and greater adherence to hand hygiene.

In spite of the knowledge acquired in time and the awareness campaigns, it was concluded that adherence to hand hygiene practices among the healthcare professionals does not comply with national and international guidelines, especially if we consider the growing number of infections caused by multidrug-resistant organisms that pose a risk to patient safety and the safety of healthcare professionals.

\section{REFERENCES}

1. Agência Nacional de Vigilância Sanitária (BR). Segurança do paciente: higienização das mãos [Internet]. Brasília, (DF); 2007 [cited 2011 oct. 12]. Available at: http://www.anvisa.gov.br/servicosaude/manuais/paciente_hig_ maos.pdf

2. Senna KMS, Melo ECP. Infecção hospitalar e os cuidados devidos. In: Figueiredo NMA, Machado WCA. Tratado de cuidados de enfermagem médico cirúrgica. Rio de Janeiro: Roca; 2012. p. 1168-74.

3. Ministério da Saúde (BR). Portaria n. 529, de 10 de abril de 2013. Institui o Programa Nacional de Segurança do Paciente (PNSP) [Internet]. Brasília (DF); 2013 [cited 2015 jul. 8]. Available at: http://bvsms.saude.gov.br/bvs/saudelegis/ gm/2013/prt0529_01_04_2013.html

4. Organização Mundial de Saúde (CH); Organização Pan-Americana da Saúde (BR); Agência Nacional de Vigilância Sanitária (BR). Guia para implementação: um guia para a implantação da estratégia multimodal da OMS para a melhoria da higienização das mãos [Internet]. Brasília, (DF); 2008. [cited 2015 jul. 08]; Available at: http://portal.anvisa.gov.br/wps/wcm/ connect/71ac2f0047457a8c873ad73fbc4c6735/guia_de_implement. pdf?MOD=AJPERES

5. Organização Pan-Americana da Saúde (BR), Agência Nacional de Vigilância Sanitária (BR). Manual do observador: estratégia multimodal da OMS para a melhoria da higienização das mãos [Internet]. Brasília, (DF); 2008. [cited 2015 jul. 08]; Available at: http://www.anvisa.gov.br/servicosaude/controle/higienizacao_oms/manual_para_observadores-miolo.pdf

6. World Health Organization (CH). WHO guidelines on hand hygiene in health care [Internet]. Geneva; 2009. [cited 2015 jul. 08]; Available at: http://homologacao-proqualis.icict.fiocruz.br/sites/default/files/WHO_Guidelines\%20 on\%20Hand\%20Hygiene\%20in\%20Health\%20Care.pdf

7. Agência Nacional de Vigilância Sanitária (BR). Segurança do paciente: relatório sobre autoavaliação para higiene das mãos [Internet]. Brasília, (DF); 2012. [cited 2015 jan. 22] Available at: http://portal.anvisa.gov.br/wps/wcm/ connect/b0708b004a5e0144be88ff45db97490b/Relat\%C3\%B3rio_de_ Avalia\%C3\%A7\%C3\%A30.pdf?MOD=AJPERES

8. Kingston General Hospital [Internet]. Kingston: KGH; 2015- [atualizado 2015 jul. 08, cited 2015 jul. 09]. Hand hygiene compliance [aprox. 2 telas]. Available at: http://www.kgh.on.ca/en/aboutkgh/strategyandperformance/Patient\%20 Safety\%20Indicators/Pages/Hand-hygiene-compliance.aspx

9. Agência Nacional de Vigilância Sanitária (BR). RDC n. 42, de 25 de outubro de 2010. Dispõe sobre a obrigatoriedade de disponibilização de preparação alcoólica para fricção antisséptica das mãos, pelos serviços de saúde do País, e dá outras providências. Diário Oficial da União [da] República Federativa do Brasil, 2010 out. 26;157(205 Seção 1):27-8.

10. Garcia SD, Gil RB, Laus AM, Haddad MCL, Vannuchi T0, Taldivo MA. Gerenciamento de recursos materiais na prática da higienização das mãos. Rev Enferm UFPE on line [Internet]. 2013 [cited 2013 jan. 02];7(5):1342-8. Available at: http://www.revista.ufpe.br/revistaenfermagem/index.php/revista/article/ view/4673/pdf_2504.

11. Prado MF, Oliveira ACJ, Nascimento TMB, Melo WA, Prado DB. Estratégia de promoção à higienização das mãos em unidade de terapia intensiva. Ciênc Cuid Saúde. 2012;11(3):557-64.

12. Guedes M, Miranda FMD, Maziero ECS, Cauduro FLF, Cruz EDA. Adesão dos profissionais de enfermagem à higienização das mãos: uma análise segundo 0 modelo de crenças em saúde. Cogitare Enferm. 2012;17(2);304-9. 
13. Akyol AD. Hand hygiene among nurses in Turkey: opinions and practices. J Clin Nurs. 2007;16(3):131-7.

14. Primo MGB, Ribeiro LCM, Fiqueiredo LFS, Sirico SCA, Sousa MA. Adesão à prática de higienização das mãos por profissionais de saúde de um Hospital Universitário. Rev Eletrônica Enferm [Internet]. 2010 [cited 2011 sept. 20];12(2):266-71. Available at: http://www.fen.ufg.br/revista/v12/n2/v12n2a06.htm

15. Neves ZCP, Tipple AFV, Souza ACS, Pereira NS, Melo DS, Ferreira LR. Higienização das mãos: 0 impacto de estratégias de incentivo à adesão entre profissionais de saúde de uma unidade de terapia intensiva neonatal. Rev Latino-Am Enfermagem. 2006;14(4):546-52.
16. Santos TCR, Roseira CE, Piai-Morais TH, Figueiredo RM. Higienização das mãos em ambiente hospitalar: uso de indicadores de conformidade. Rev Gaúcha Enferm. 2014;35(1):70-7.

17. Findik UY, Otkun MT, Erkan T, Sut N. Evaluation of handwashing behavior and analysis of hand flora of intensive care unit nurses. Asian Nurs Res. 2011:5(2):99-107.

18. Silva BV, Cardoso CMS, Nascimento SMC, Madeira MZA. Adesão da higienização das mãos por profissionais de saúde em unidade de terapia intensiva neonatal. Rev Enferm UFPI. 2013;2(1):33-7.

19. Oliveira AC, Paula A0. Monitoração da adesão à higienização das mãos: uma revisão de literatura. Acta Paul Enferm. 2011;24(3):407-13.

\section{Author's address:}

Luccas Melo de Souza

Av. Itacolomi, 3600, São Vicente

94155-052 Gravataí - RS

E-mail: luccasms@gmail.com
Received: 23.07.2014

Approved: 05.08.2015 